\title{
AKTIVITAS AFRODISIAKA MINYAK ATSIRI KUNCUP \\ BUNGA CENGKEH (Syzygium aromaticum (L.) Merr. \& Perry.)
}

\section{APHRODISIAC ACTIVITY OF ESSENTIAL OIL FROM Syzygium aromaticum (L.) Merr. \& Perry}

\author{
Arifah Sri Wahyuni*, Nurcahyanti Wahyuningtyas dan Arifiyanti \\ Fakultas Farmasi, Universitas Muhammadiyah Surarakarta \\ arifah_sriwahyuni@yahoo.com
}

\begin{abstract}
ABSTRAK
Kuncup bunga cengkeh (Syzygium aromaticum (L.) Merr. \& Perry.) telah dilaporkan memiliki aktivitas sebagai afrodisiaka. Kandungan senyawa sterol dan fenolik diduga berkhasiat sebagai afrodisiaka. Penelitian ini bertujuan untuk untuk mengetahui efek afrodisiak minyak atsiri kuncup bunga cengkeh pada tikus putih jantan.Minyak atsiri kuncup bunga cengkeh dosis 6,25, 12,5 dan $25 \mathrm{mg} / \mathrm{kgBB}$ diberikan satu kali sehari selama 7 hari pada tikus putih jantan $(n=6)$. Pengamatan dilakukan terhadap parameter Mounting Latency (ML) dan Mounting Frequency (MF). Hasil menunjukkan bahwa minyak atsiri kuncup bunga cengkeh memiliki efek afrodisiak (peningkatan libido) pada tikus putih jantan. Nilai ML menunjukkan 3,0 \pm 1 (menit) dan nilai MF yang diamati dalam waktu 2 jam adalah 77,4 $\pm 4,1$ kali.
\end{abstract}

Kata kunci : Aprodisiaka, Kuncup Bunga Cengkeh,

\section{ABSTRACT}

Clove (Syzygium aromaticum (L.) Merr. \& Perry.) has been reported aphrodisiac. This study is aimed to investigated the effect of essential oils of clove on general mating behavior libido on sexually normal male albino rats. The essential oil was administered orally at dose 6.25, 12.5 and $25 \mathrm{mg} / \mathrm{kgBB}$, to different group of male rats $(n=5)$ once a day for seven days. The Mounting Latency (ML) and Mounting Frequency (MF) were determined and compared with Tribulus trietteris. This results showed that the essential oil of clove dose of 12.5 and $25 \mathrm{mg} / \mathrm{kgBB}$ have aphrodisiac effects (increased libido) in male rats. Dose of $25 \mathrm{mg} / \mathrm{kgBB}$ showed valueof ML was 3,0 \pm 1 (minute) and 77,4 $\pm 4,1$ times for MF value.

Keywords : aphrodisiac, Essential oils of clove, (Syzygium aromaticum (L.) Merr. \& Perry.), , Mounting Latency (ML), Mounting Frequency (MF).

\section{PENDAHULUAN}

Gangguan seksual lebih sering terjadi pada pria daripada wanita. Prevalensinya $10 \%$ terjadi pada semua usia, lebih dari $50 \%$ terjadi pada pria dengan usia antara 50 dan 70 tahun dan $40 \%$ dengan penurunan sel Leydig dan penurunan luteinizing hormone (LH) (Yakubu et al., 2007). National Health and Social Life Survey (NHSLS) dan Massachusetts Male Aging Study (MMAS) Amerika pada tahun 1992 meneliti bahwa pertambahan usia pada pria secara positif berhubungan dengan penurunan libido. Pria dengan usia 50-59 tahun prevalensi penurunan libido tiga kali lebih tinggi dari pria dengan usia lebih muda (Laumann et al., 1999). Pengatasan gangguan seksual salah satunya dengan menggunakan afrodisiaka, yaitu suatu bahan organik, minyak esensial (minyak atsiri), obat, minuman herbal atau bahan yang dapat membangkitkan gairah seksual (Oktavina, 2006)

Kuncup bunga cengkeh (Syzygium aromaticum (L.) Merr. \& Perry). merupakan salah satu tanaman yang diduga mempunyai khasiat sebagai afrodisiaka. Penelitian pendahuluan menyebutkan bahwa ekstrak etanol 50\% kuncup bunga cengkeh (Syzygium aromaticum (L.) Merr. \& Perry.) dosis 100, 250 dan $500 \mathrm{mg} / \mathrm{kg}$ dapat meningkatkan aktivitas seksual dan libido tikus jantan (Tajuddin et al., 2004). Efek ini kemungkinan dikontribusi oleh kandungan kimia kuncup bunga cengkeh, eugenol (Sumalatha et al., 2010). Eugenol, sebagai senyawa utama dalam bunga cengkeh dilaporkan terlibat dalam aktivitas enzim superoxidase dismutase, katalase, glutathione peroxidase- 6 phosphate dehydrogenase dan juga mempunyai aktivitas menghambat lipid peroksidase (Kumarvelu et al., 1996) dan juga dilaporkan mempunyai aktivitas vasodilator (Criddle et al., 2003). Efek vasodilator ini akan membantu menyediakan suplai darah yang cukup di organ kelamin pria, sehingga akan memperlama terjadinya ereksi.

Kuncup bunga cengkeh mempunyai kandungan minyak atsiri cukup besar dengan 
kadar eugenol sebesar 64-85 yang diduga mempunyai aksi yang sama dengan ekstrak etanol kuncup bunga cengkeh sebagai afrodisiaka (Criddle et al., 2003). Oleh karena itu perlu dilakukan penelitian untuk memberikan bukti ilmiah khasiat minyak atsiri bunga cengkeh sebagai aprodisiaka.

\section{METODE PENELITIAN}

\section{Alat dan Bahan}

a. Bahan uji : simplisia kuncup bunga cengkeh tua yaitu dipanen sebelum bunga mekar yang diperoleh dari Balai Besar Penelitian dan Pengembangan Tanaman Obat dan Obat Tradisional (B2P2TO2T) di Tawangmangu, Jawa Tengah.

b. Bahan pembanding : Tribulus terrestris sebagai kontrol positif dan tween 80 sebagai kontrol negatif.

c. Bahan tambahan : natrium sulfat anhidrat (p.a), gel xylocaine 2\%, akuades (teknis), etanol (teknis), silica gel GF 254 (Merck), toluen (p.a), etil asetat (p.a), eugenol, vanilin (p.a), dan asam sulfat (p.a).

d. Hewan uji yang digunakan adalah tikus putih jantan dan betina galur Wistar (umur 8-12 minggu) dengan berat badan 100-200 g, yang diperoleh dari Unit Pemeliharaan Hewan Uji Bagian Farmakologi Fakultas Farmasi Universitas Muhammadiyah Surakarta. Tikus diadaptasikan terlebih dahuklu selam kurang lebih 2 minggu.

\section{Jalannya Penelitian \\ Preparasi sediaan}

Variasi dosis minyak atsiri yang digunakan untuk uji adalah 6,25, 12,5 dan 25 $\mathrm{mg} / \mathrm{kgBB}$ diemulsikan dengan $1 \%$ tween 80 . Dosis Tribulus terrestris yang digunakan adalah $5 \mathrm{mg} / \mathrm{kgBB}$ yang diemulsikan dengan tween 80 .

\section{Uji afrodisiaka}

Sejumlah 35 (tiga puluh lima) ekor tikus uji dikelompokkan menjadi 5 kelompok uji, masing-masing kelompok terdiri dari 5 ekor tikus jantan. Pemberian sediaan uji dilakukan secara per oral, satu kali sehari pada jam 18.00 selama 7 hari dengan volume pemberian 2,5 ml/200 gBB sebagai berikut:
Kelompok I (Kontrol positif):Tribulus terrestris dosis $5 \mathrm{mg} / \mathrm{kgBB}$

Kelompok II (Kontrol negatif):tween 80 1\% .

Kelompok III:emulsi minyak atsiri dosis 6,25 $\mathrm{mg} / \mathrm{kgBB}$

Kelompok IV:emulsi minyak atsiri dosis 12,5 $\mathrm{mg} / \mathrm{kgBB}$

Kelompok $\mathrm{V}$ :emulsi minyak atsiri dosis 25 $\mathrm{mg} / \mathrm{kgBB}$

Pengamatan dilakukan pada hari ke-7 jam 20.00 sampai dengan jam 22.00. Satu tikus jantan dan satu tikus betina dimasukkan dalam satu kandang. Tiga puluh (30) menit sebelum pengamatan penis tikus jantan diolesi gel xylocaine $2 \%$. Parameter yang diamati meliputi Mounting Latency (ML) yaitu waktu perkenalan tikus jantan ke dalam kandang tikus betina sampai tunggangan pertama dan dan Mounting Frequency (MF) yaitu jumlah tunggangan sebelum ejakulasi. Data Mounting Latency (ML) dan data Mounting Frequency (MF). Data diuji dengan General Linear Model-Multivariate. Apabila hasilnya berbeda bermakna maka analisis dilanjutkan dengan uji Post Hoc-Tukey $H S D$ dengan taraf kepercayaan $95 \%$.

\section{Uji Kromatografi Lapis Tipis (KLT)}

Uji dilakukan dengan menotolkan minyak atsiri pada lempeng kromatografi lapis tipis. Pembanding yang digunakan adalah minyak atsiri eugenol. Pemilihan fase diam, fase gerak dan deteksi bercak adalah:

a. Fase diam: silica gel GF 254

b. Fase gerak : toluen-etil asetat (93:7)

c. Pereaksi penampak bercak:vanilin-asam sulfat

\section{HASIL DAN PEMBAHASAN \\ Hasil Destilasi Minyak Atsiri}

Minyak atsiri yang diperoleh dari penyulingan $1 \mathrm{~kg}$ bahan kuncup bunga cengkeh adalah sebanyak $60 \mathrm{ml}$, sehingga rendemen yang diperoleh $6 \%$. Organoleptis minyak atsiri yang dihasilkan mempunyai bau yang khas, rasa getir agak pedas dengan warna kuning bening. Destilat mempunyai bobot jenis 1,06 dan indeks bias 1,527. Hasil uji KLT menunjukkan RF 0,69. Destilat ini memiliki kesamaan dengan standard eugenol (Tabel 1).

Tabel 1- Hasil pemeriksaan fisik minyak atsiri kuncup bunga cengkeh hasil destilasi

\begin{tabular}{lccc}
\hline \multicolumn{1}{c}{ Pemeriksaan } & Indeks Bias & Bobot Jenis & Harga Rf $^{*}$ \\
\hline Standard & $1,527-1,541$ & $1,025-1,06$ & 0,66 \\
Destilat & 1,527 & 1,06 & 0,69 \\
\hline${ }^{*}$ deteksi dengan pereaksi semprot vanillin-asam sulfat & &
\end{tabular}

*deteksi dengan pereaksi semprot vanillin-asam sulfat 


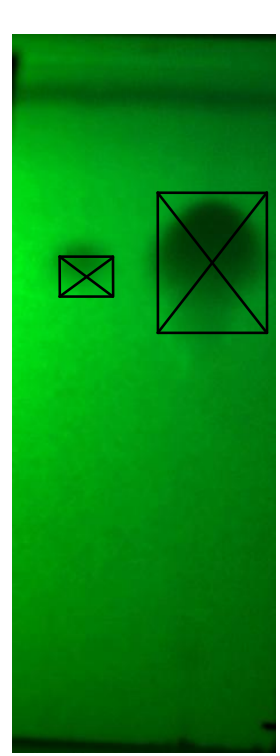

a

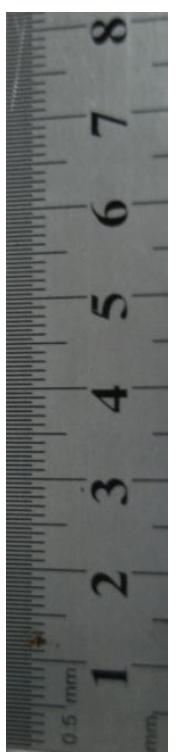

S P

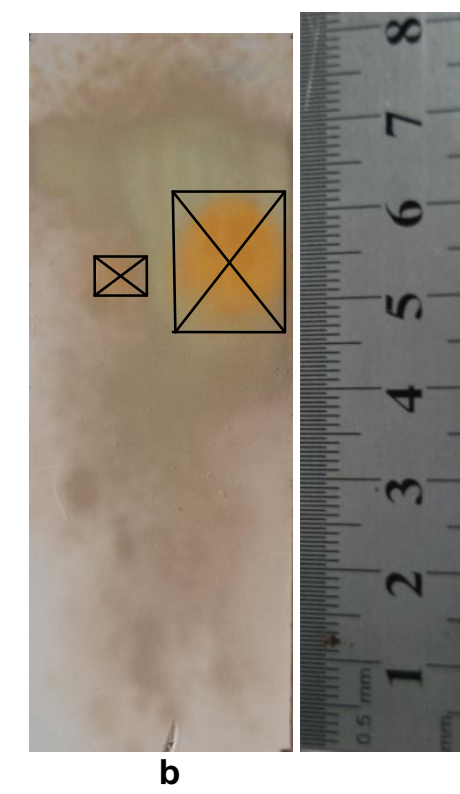

S

Gambar 1- Hasil Analisis Kromatografi Lapis Tipis terhadap Minyak Atsiri Kuncup Bunga Cengkeh dan Pembanding Eugenol. (a). Pereaksi semprot vanilin-asam sulfat di bawah sinar $U_{254}$, (b). Pereaksi semprot vanilin-asam sulfat di bawah sinar tampak

Keterangan :

$P$

Fase diam

Fase gerak

Jarak pengembangan

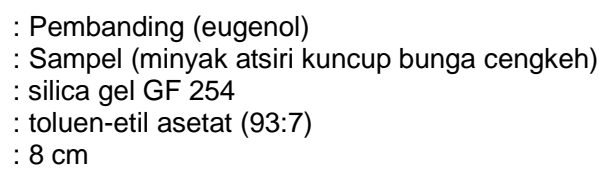

\section{Uji Afrodisiaka}

Kemampuan kuncup bunga cengkeh sebagai afrodisiaka diindikasikan dari peningkatan libido hewan uji jantan. Libido dapat diamati dari parameter mounting latency (ML) dan mounting frequency (MF) (Tabel 2).. Ketertarikan hewan jantan terhadap betina dinilai dari parameter ML. Harga ML menunjukkan onset sediaan. Hasil pengamatan

menunjukkan bahwa pemberian minyak atsiri kuncup bunga cengkeh dosis 12,5 dan 25 $\mathrm{mg} / \mathrm{kgbb}$ mempunyai kemampuan memperpendek mounting latency. Penurunan harga ML mengindikasikan bahwa sediaan minyak atsiri kuncup bunga cengkeh mempunyai kemampuan mempercepat libido $(p<0,05)$.

Tabel 2- Purata harga mounting latency dan mounting frequency pada berbagai dosis pemberian minyak atsiri kuncup bunga cengkeh $(n=5)$

\begin{tabular}{cccccc}
\hline Parameter & $\begin{array}{c}\text { Tribulus trieteris } 5 \\
\text { mg/kgbb }\end{array}$ & $1 \%$ Tween 80 & $\begin{array}{c}\text { Minyak atsiri dosis } \\
6,25 \mathrm{mg} / \mathrm{kgbb}\end{array}$ & $\begin{array}{c}\text { Minyak atsiri } \\
\text { dosis 12,5 } \\
\mathrm{mg} / \mathrm{kgbb}\end{array}$ & $\begin{array}{c}\text { Minyak atsiri } \\
\text { dosis } 25 \\
\mathrm{mg} / \mathrm{kgbb}\end{array}$ \\
\hline $\begin{array}{c}\text { Monting } \\
\text { Latency (ML) }\end{array}$ & $2,2 \pm 0,7$ & $45,0 \pm 10,3$ & $26,2 \pm 21,98^{*}$ & $1,5 \pm 0,4$ & $3,0 \pm 1,7$ \\
$\begin{array}{c}\text { Monting } \\
\text { Frequency } \\
\text { (MF) }\end{array}$ & $43,2 \pm 4,9$ & $5,8 \pm 1,65$ & $32,8 \pm 21,7$ & $53,0 \pm 5,6$ & $77,4 \pm 4,1$ \\
\hline
\end{tabular}

${ }^{\star}$ tidak signifikan dengan kontrol negatif $(p>0,05)$

Intensitas efek libido ditunjukkan dari parameter mounting frequency (MF) atau banyaknya tunggangan tikus jantan pada tikus betina. Tikus jantan sebelum ditempatkan dengan dosen betina diolesi dengan xylocaine yang berlaku sebagai vasodilator, yang akan memperlebar pembuluh darah, sehingga akan memperpanjang masa ereksi. Semakin tinggi harga MF maka menunjukkan intensitas efek sediaan tersebut semakin besar. Kuncup bunga cengkeh mampu meningkatkan harga MF tikus jantan pada dosis $12,5 \mathrm{mg} / \mathrm{kgbb} \quad(\mathrm{p}<0,05)$. Bahkan intensitas efeknya lebih besar dibandingkan dengan pemberian Tribulus terrestris $(p<0,05)$. 
Kontrol positif yang digunakan adalah Tribulus terrestris (TT), Kandungan aktif tanaman ini adalah steroid, saponin, flavonoid,alkaloid, asam lemak tak jenuh, vitamin, tanin. Kandungan aktif utama adalah saponin tipe furostanol, yang disebut protodioscin yang menunjukkan bahwa ekstrak Tribulus terestris dapat meningkatkan fungsi reproduksi (libido) pada manusia, tikus, dan mencit (Grigorova, et al., 2008). Tanaman ini juga telah diteliti mempunyai kemampuan meningkatkan waktu tunggangan, intromisi dan ejakulasi (Gauthaman et al., 2002). Efek ini kemungkinan diperantarai dengan mekanisme meningkatkan testosteron dan androgen (ElTantawy et al., 2007). Sementara sebagai kontrol negatif digunakan adalah $1 \%$ tween 80 , sebagai emulgator yang mampu mengemulsikan destilat minyak atsiri kuncup bunga cengkeh.

Efek peningkatan libido setelah pemberian minyak atsiri kuncup bunga cengkeh diduga dari kandungan kimia cengkeh yaitu senyawa sterol dan fenolik (Tajuddin et al., 2004). Salah satu dari senyawa fenolik adalah eugenol, merupakan komponen terbesar penyusun minyak atsiri kuncup bunga cengkeh. Eugenol merupakan senyawa yang diduga kuat berefek sebagai afrodisiaka karena dilaporkan mempunyai aktivitas vasodilator (Criddle et al., 2003).

Hasil penelitian tersebut dapat dinyatakan bahwa eugenol merupakan senyawa pada tanaman cengkeh yang paling bertanggung jawab dalam efek afrodisiak (peningkatan libido). Senyawa ini kemungkinan dapat meningkatkan neurotransmitter pada tingkat seluler sehingga akan menstimulasi syaraf dan berakibat pada terjadinya perubahan perilaku seksual terutama meningkatnya libido.

\section{KESIMPULAN}

Minyak atsiri kuncup bunga cengkeh dengan kandungan senyawa aktif eugenol terbukti memiliki efek afrodisiak (peningkatan libido) pada tikus jantan.

\section{UCAPAN TERIMAKASIH}

Terimakasih diucapkan kepada DIKTI melalui program Hibah Dosen Muda tahun 2010.

\section{DAFTAR PUSTAKA}

Criddle, D. N., S. V. Madeira, and S. D. Moura, 2003, Endothelium -dependent and - independent vasodilator effects of eugenol in the rat mesentric vascular bed: J Pharm Pharmacol, v. 55, p. 359365.

El-Tantawy, W. H., A. Temraz, and O. D. El-Gindi, 2007, Free serum testosterone level in male rats treated with Tribulus alatus extracts: Int Braz J Urol, v. 33(4), p. 554-8.

Gauthaman, K., P. G. Adaikan, and R. N. Prasad, 2002, Aphrodisiac properties of Tribulus Terrestris extract (Protodioscin) in normal and castrated rats: Life Sci, v. 71(12), p. 1385-96.

Grigorova, S., B. Kashamov, V. Sredkova, S. Surdjiiska, and H. Zlatev, 2008, Effect of Tribulus terrestris Extract on Semen Quality and Serum Total Cholesterol Content in White Plymouth RockMini Cocks: Biotechnology in Animal Husbandry, v. 24, p. 139-146.

Kumarvelu, P., S. Subramanyam, M. D. P. Dakshin, and N. S. Devraj, 1996, The antioxidant effect of eugenol on carbon tetrachloride-induced erythrocyte damage in rats: Nut Biochem, v. 7, p. 2328.

Laumann, E. O., A. Paik, and R. C. Rosen, 1999, Sexual Dysfunction in the United StatesPrevalence and Predictors, Review Urology, (online),.

Oktavina, D. M., 2006, 20 Ramuan Afrodisiak Nusantara Pembangkit Gairah: Jakarta, Esensi.

Sumalatha, K., S. Kumar, and M. Lakshmi, 2010, Review On Natural Aphrodisiac Potentials To Treat Sexual Dysfunction: International Journal of Pharmacy \& Therapeutics, v. 1, p. 10-18.

Tajuddin, S. Ahmad, A. Latif, and I. A. Qasmi, 2004, Effect of 50\% ethanolic extract of Syzygium aromaticum (L.) Merr. \& Perry. (clove) on sexual behaviour of normal male rats: BMC Complementary and Alternative Medicine, v. 4:17, p. 1-7.

Yakubu, M. T., M. A. Akanji, and A. T. Oladiji, 2007, Male Sexual Dysfunction and Methods used in Assessing Medicinal Plants with Aphrodisiac Potentials: Pharmacognosy Reviews, v. 1, p. 49-56. 